\title{
Effect of the surfactant Corexit 7664 on uptake of cadmium by organisms and biological matter in a closed circulated brackish-water system
}

\author{
H. von Westernhagen ${ }^{1} \&$ V. Dethlefsen ${ }^{2}$ \\ ${ }^{1}$ Biologische Anstalt Helgoland (Zentrale); Notkestr. 31, D-2000 Hamburg 52, \\ Federal Republic of Germany \\ ${ }^{2}$ Bundesforschungsanstalt für Fischerei, Institut für Küsten- und Binnenfischerei, \\ Toxikologisches Laboratorium Cuxhaven; Niedersachsenstraße, D-2190 Cuxhaven, \\ Federal Republic of Germany
}

\begin{abstract}
Juvenile flounder and common mussel from the Baltic Sea were kept in Corexit 7664 $(50 \mu \mathrm{g} / \mathrm{l})$ and cadmium $(5 \mu \mathrm{g} / \mathrm{l})$-contaminated, recirculated, sea-water systems for 200 days at $15^{\circ} \mathrm{C}$ and $20 \% \mathrm{~S}$. Accumulation of cadmium with exposure time was measured in several fish tissues and in mussel. There were no differences in the cadmium accumulation by tissues with or without the addition of Corexit 7664. No acute effects of the contaminants on the experimental animals could be noted. Final cadmium concentrations, reached for all biological matter analysed, were 4 times higher than in full-strength sea water.
\end{abstract}

\section{INTRODUCTION}

Cadmium concentration in man has increased considerably during the past century, as shown by Elinder \& Kjelström (1977), and despite the blacklisting of cadmium in the water protection conventions, the total cadmium load entering estuaries and coastal waters is still considerable. Particularly coastal and shallow-water living organisms inhabit water bodies with elevated metal concentrations caused by coastal sewage or waste water outlets (Abdullah et al., 1972; Harms, 1975; Harris et al., 1979; Hershelman et al., 1981), or simply through desorption of heavy metals from suspended material in waters of increasing salinity (van der Weijden et al., 1977; Duinker \& Nolting, 1978).

Thus, the accumulation of cadmium by Mytilus edulis, both in the natural habitat and in the experiment, has been the subject of many recent pollution studies (Phillips 1976; Phillips, 1977; George \& Coombs, 1977; Karbe et al., 1977; Harris et al., 1979; Coleman, 1980 and others). The uptake of cadmium by fish and its concentration in fish muscle has also been described in several publications; the papers of Calabrese et al. (1975), and Larsson et al. (1981) deal with the response of flounders to experimental cadmium exposure.

Whereas fish muscle generally contains only small amounts of cadmium (Topping, 1973; Pentreath, 1977; Noël-Lambot \& Bouquegneau, 1977) the simultaneous action of a surfactant, known to be toxic and used for dispersing oil or cleansing after oil spills 
(Nelson-Smith, 1968), and a heavy metal might influence accumulation of the metal to such an extent that the edible parts of commercially important fish might become unfit for human consumption.

Thus, this study was undertaken to investigate how the action of a surfactant may influence the uptake of cadmium by marine organisms.

\section{MATERIALS AND METHODS}

Recirculated sea water system. The experiments were conducted in 4 semi-closed, recirculated brackish-water (ca $20 \%$ S) systems with a capacity of 1501 each. The water was treated in 601 biological cockleshell-grit-gravel filters, then pumped into a header tank from where it flowed by gravity into the fish basins. Water flow through the filters was $20 \mathrm{l} / \mathrm{min}$. Water flow through the fish basins was $1.2 \mathrm{l} / \mathrm{min}$. The basins $(90 \times 90 \times 20 \mathrm{~cm})$ contained $100 \mathrm{l}$ sea water each. From the fish basins the waste water passed through the filter unit. 50 days prior to the start of the experiments all systems were stocked with flounders in order to build up a bacterial population in the biological filter. At the start of the experiments $\mathrm{CdCl}_{2}$ was added to two systems until a cadmium concentration of about $5 \mu \mathrm{g} / \mathrm{l}$ in the water was reached. In two systems Corexit 7664, a non-ionic tensid, was added to reach an initial concentration of $50 \mu \mathrm{g} / \mathrm{l}$. Thus the procedure resulted in 4 different water regimes: one control system without any additive, one system with $50 \mu \mathrm{g}$ Corexit/1, one with $5 \mu \mathrm{g} \mathrm{Cd} / 1$ and one with $50 \mu \mathrm{g}$ Corexit/ 1 plus $5 \mu \mathrm{g} \mathrm{Cd} / 1$. Every week $10 \%$ of the water in each system was replaced with new water of the respective kind. Water quality parameters were controlled regularly. Cadmium determination in the system was conducted daily. The experiments were performed at 13.3-16.2 ${ }^{\circ} \mathrm{C}$ (mean: $14.8 \pm 0.6$ ) in brackish water with a salinity of about $20 \%$ (mean: $20.8 \pm 0.7)$.

F 1 o u n d e r. Juvenile flounder (Platichthys flesus [L.]) (5.0-10.0 g) were caught in the Baltic Sea and transferred to the laboratory where they were allowed to acclimatize for 4 weeks at $15{ }^{\circ} \mathrm{C}$ and $20 \%$ salinity in a recirculated brackish-water system. 30 fish were then transferred to each experimental basin. The fish were fed alternately two daily rations of minced, fresh Mytilus edulis meat or a ground fish-shrimp mixture at rates of $15 \%$ food wet weight of their total body weight. Cadmium content of mussels used for food was $0.3 \mathrm{ng} / \mathrm{mg}$ dry wt and the fish-shrimp mixture contained between 0.25 and $0.38 \mathrm{ng} \mathrm{Cd} / \mathrm{mg}$ dry wt throughout the experiment. The fish were measured and weighed every 14 days. At regular intervals individuals were sacrificed and samples of tissue were taken for cadmium analysis (backbone, fins, gills, liver, muscle, otoliths, skin).

Muss el. Throughout the experiment, mussels (Mytilus edulis) from the Baltic Sea were kept without feeding on the biological filter (40 specimens in each system; valve length ca. $5.0 \mathrm{~cm}$ ). Accumulation of cadmium by mussels in the digestive gland and total soft tissue was measured at regular exposure time intervals.

$\mathrm{Bi}$ ol o g i cal s l u d g e. With the activation of the filter system, biological sludge, consisting of bacteria and meiofauna (mainly nematodes, harpacticids and ciliates), developed in the gravel filter. Throughout the experiment this "sludge" was collected after stirring the upper $2 \mathrm{~cm}$ of the filter and was then analysed for cadmium content.

$\mathrm{Cadmi}$ u $\mathrm{m}$ eter min ation. Determination of cadmium was accomplished by means of a flameless atomic absorption spectrophotometer equipped with an electrode- 
less discharge lamp. Prior to cadmium determination the dried biological matter was digested in a mixture of $\mathrm{HNO}_{3}$ and $\mathrm{HClO}_{4}(1: 4)$ at $60^{\circ} \mathrm{C}$ for $24 \mathrm{~h}$.

Corexit concentration. The surfactant Corexit 7664 was dosed at concentrations of $50 \mu \mathrm{g}$ Corexit/l into the systems. Analysis of uptake by organisms or rate of biodegradation was not performed. Actual concentrations of the surfactant had to be considered as having decreased from an initial $50 \mu \mathrm{g} / 1$ to $10 \mu \mathrm{g} / 1$ within 6 weeks, assuming the same rate of biodegradation as shown by Mann \& Schöberl (1976) for a non-ionic surfactant $\left(\mathrm{C}_{13-14}\right.$ oxoalcohol) tested at concentrations of 10.0 to $12.0 \mathrm{mg} / \mathrm{l}$.

\section{RESULTS}

\section{Experimental water}

Figure 1 shows the course of water-cadmium concentration in the 4 systems during the experiments. During the first 150 days, cadmium in the contaminated systems was around 5.0 to $7.0 \mu \mathrm{g} / 1$, falling later to 3.0 to $5.0 \mu \mathrm{g} / \mathrm{l}$. In the designated control system, cadmium concentration was always roughly $0.5 \mu \mathrm{g} / 1$ higher than in the Corexit treated one, probably because the latter was newly installed while the former had already acquired a slightly elevated background level during former use.

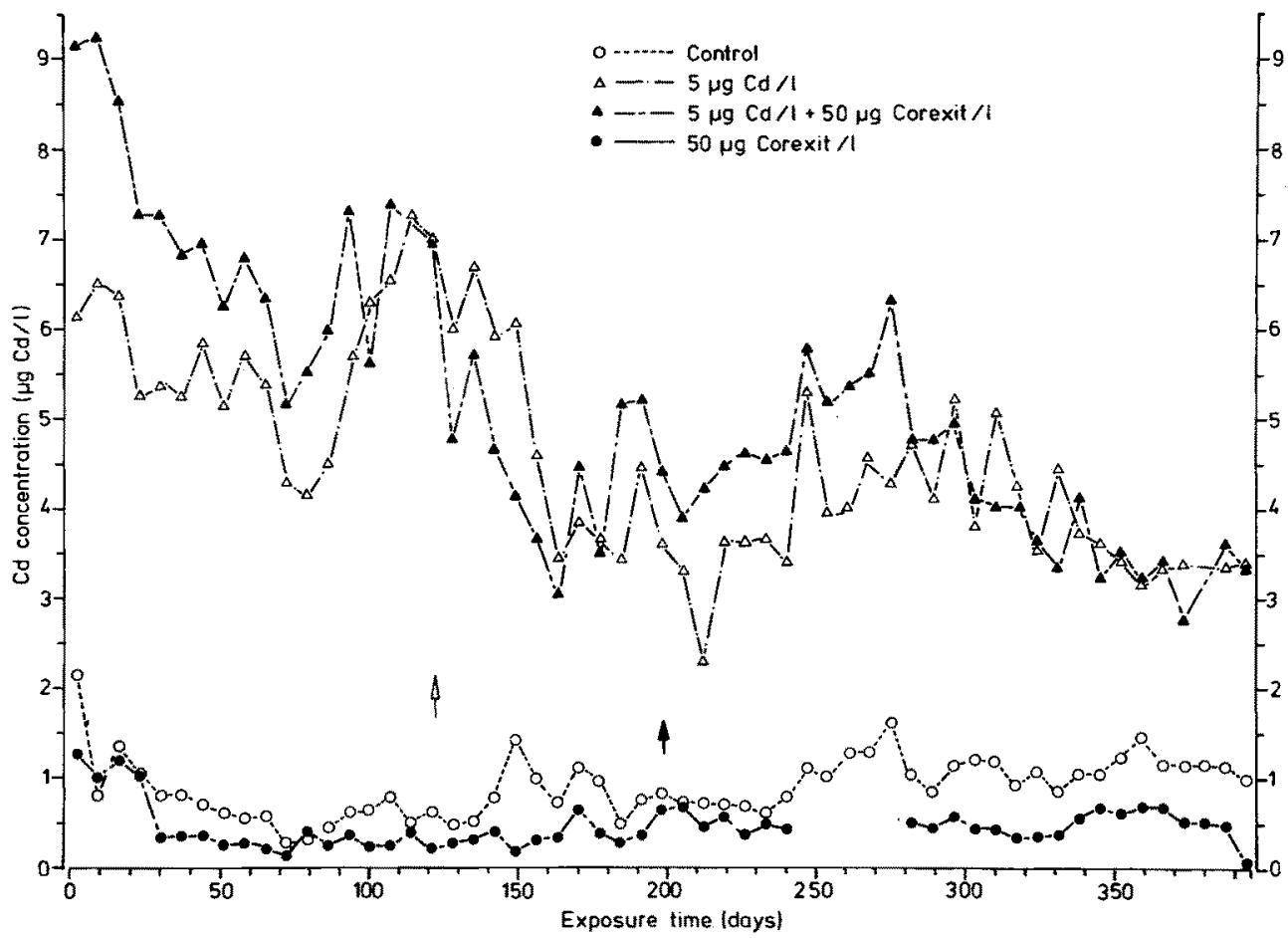

Fig. 1. Weekly means of cadmium concentration in the water of 4 experimental brackish-water (20\% S) recirculated systems. Open arrow: introduction of mussels into the system; solid arrow: end of cadmium dosing 


\section{Accumulation of cadmium by filter sludge}

In Figure 2 the cadmium content of the sludge from the control and contaminated systems are depicted. Both systems, the control and the solely Corexit 7664 treated systems, were low in sludge cadmium. The sludge of the metal contaminated systems, however, showed in time an increase in the cadmium content.

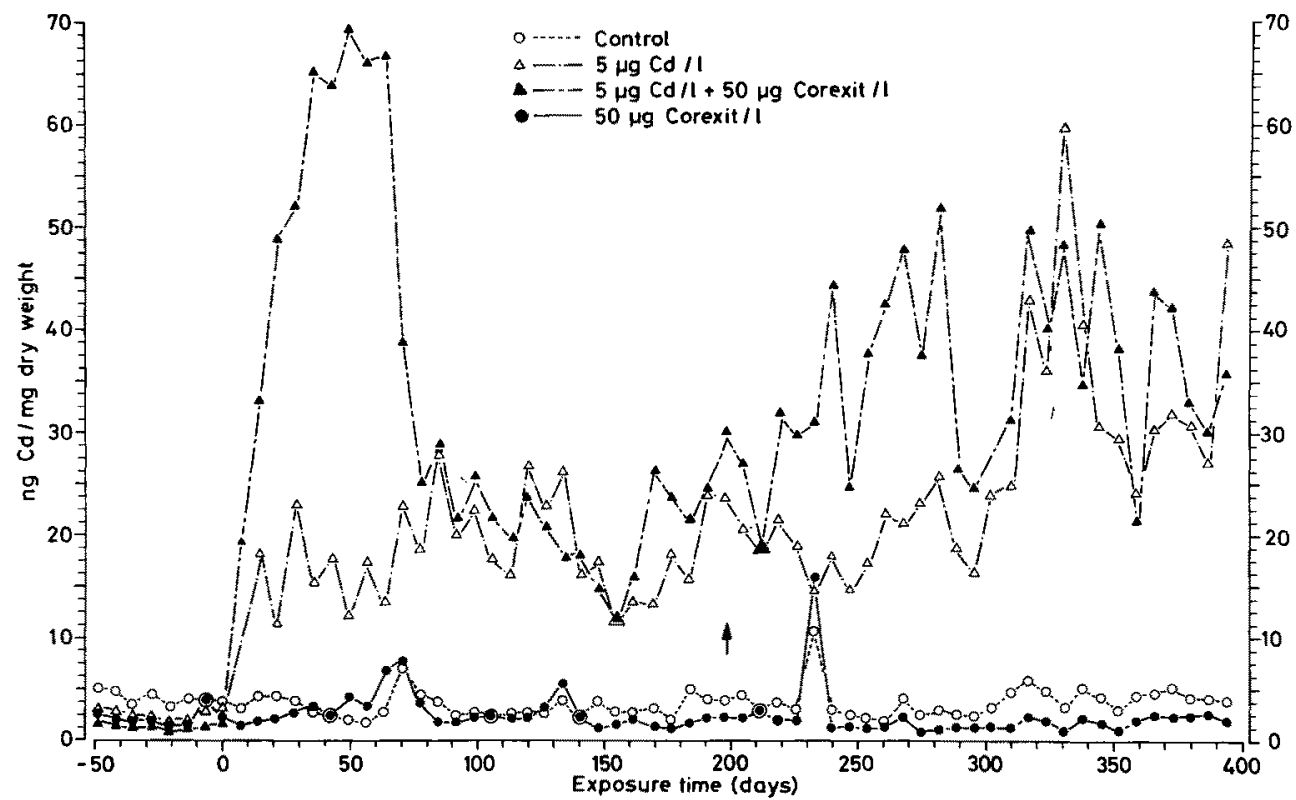

Fig. 2. Accumulation of cadmium by "sludge" derived from a biological filter in a recirculated brackish-water $(20 \% \mathrm{~S})$ system with untreated and Cd-contaminated $(5 \mu \mathrm{g} \mathrm{Cd} / \mathrm{l})$ water with and without the surfactant Corexit $7664(50 \mu \mathrm{g} / \mathrm{l})$. Water temp.: $15^{\circ} \mathrm{C}_{\boldsymbol{i}}$ values displayed as weekly means calculated from daily samples; arrow indicates end of cadmium dosing

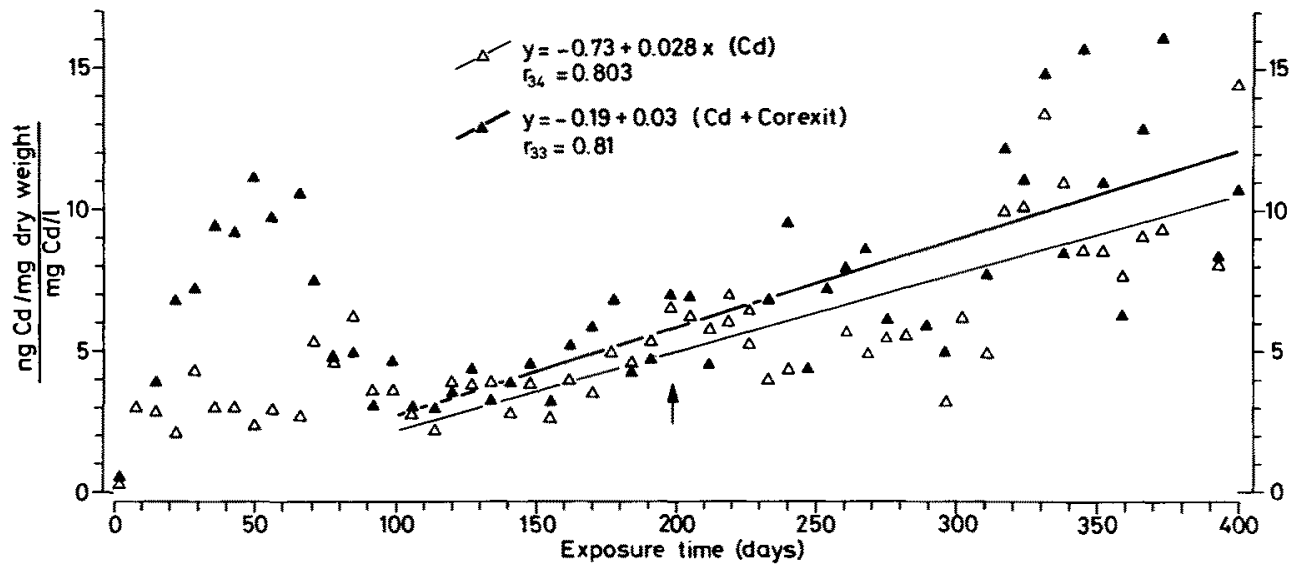

Fig. 3. Accumulation of cadmium by "sludge" derived from a biological filter (see legend of Fig. 2). Cadmium accumulation depicted in relation to actual cadmium concentration in the water. Arrow indicates end of cadmium dosing 
Except for the first 70 days after the addition of cadmium, when the cadmium load was several times higher in the sludge from the system treated with cadmium and surfactant, the process of cadmium concentration in both organic matter was similar. Although the absolute cadmium values in the sludge of both systems showed at times considerable differences, the slopes of the linear regression lines calculated for the cadmium concentration on the basis of the prevailing water cadmium concentrations (Fig. 3) showed no significant differences between the two systems. Accumulation was linear and after some 350 days of exposure to $5.0 \mu \mathrm{g} \mathrm{Cd} / 1$, concentrations reached from between 30 to $50 \mathrm{ng} \mathrm{Cd/mg} \mathrm{dry} \mathrm{wt} \mathrm{sludge} \mathrm{(Fig.} \mathrm{2).}$

\section{Accumulation of cadmium by mussels}

A rapid increase in cadmium content after exposure to this metal could be observed in the soft tissue and the digestive gland of $M$. edulis (Fig. 4) in water with and without the addition of Corexit 7664. At the start of the experiment, cadmium concentration in the experimental animals amounted to $0.3 \mathrm{ng} \mathrm{Cd} / \mathrm{mg}$ dry wt; after 250 days of exposure to cadmium it rose to as much as $800 \mathrm{ng} \mathrm{Cd} / \mathrm{mg}$ dry tissue and more than $1500 \mathrm{ng} \mathrm{Cd} / \mathrm{mg}$ dry wt in the digestive gland. As can be seen from Figure 4 the increase in cadmium content was linear and there were practically no differences in the accumulation process with or without Corexit 7664. In the "cadmium free" systems only small amounts of the metal were accumulated by the test organisms.

\section{Accumulation of cadmium by flounder}

From former studies on plaice (Westernhagen et al., 1980) we knew that accumulation of cadmium in fish was best traceable in the liver and thus development of cadmium concentration in the liver upon exposure to the metal is referred to in Figure 5. Cadmium concentration in the liver of control specimens increased more than for the "surfactant only" specimens. In neither of these sampled fish though did liver cadmium exceed $2.0 \mathrm{ng} \mathrm{Cd} / \mathrm{mg}$ dry wt. Liver cadmium of specimens from the metal contaminated systems, however, increased from $0.5 \mathrm{ng} \mathrm{Cd} / \mathrm{mg}$ dry wt to around $20 \mathrm{ng} \mathrm{Cd} / \mathrm{mg}$ dry wt after 199 days. In both systems, with and without Corexit 7664, accumulation of cadmium was non-linear and proceeded almost identically $\left(5 \mu \mathrm{g} \mathrm{Cd}: \mathrm{y}=0.722 \mathrm{e}^{0.0128 \mathrm{x}} ; 5 \mu \mathrm{g} \mathrm{Cd}+\right.$ Corexit: $y=0.602 \mathrm{e}^{0.0145 \mathrm{x}}$ ).

The other tissues examined did show slightly elevated cadmium content after exposure to the metal, but accumulation was not pronounced. For instance in fillet, cadmium content increased in time following the function $y=0.05+0.001 \mathrm{x}, \mathrm{r}_{10}=0.54$, for the $5 \mu \mathrm{g} \mathrm{Cd} / 1$ trial and $\mathrm{y}=0.045+0.001 \mathrm{x}, \mathrm{r}_{10}=0.48$, for the $5 \mu \mathrm{g} \mathrm{Cd} / 1$ plus Corexit trial. The slopes for both functions were almost identical and increase in cadmium content was not significant at the $5 \%$ level. Cadmium concentration in muscle tissue ranged from $0.05 \mathrm{ng} / \mathrm{mg}$ dry wt at day zero to $0.25 \mathrm{ng} \mathrm{Cd} / \mathrm{mg}$ dry wt after 200 days of exposure.

In none of all the tissues examined was the increase of cadmium content higher in those derived from the specimens treated with cadmium plus Corexit than in those treated with cadmium only. 

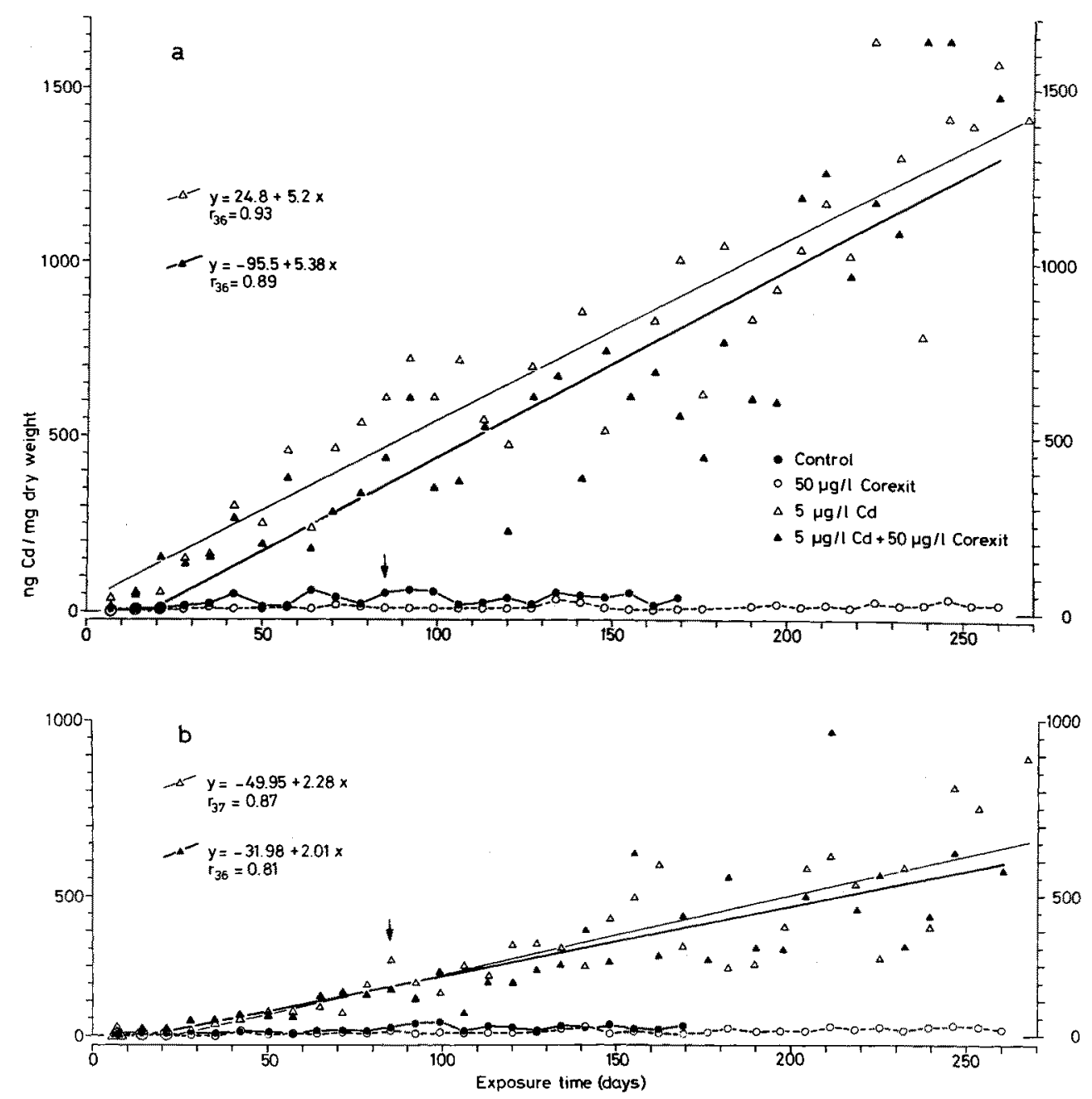

Fig. 4. Accumulation of cadmium by digestive gland (a) and soft tissue (b) of Mytilus edulis kept in an untreated and a cadmium-contaminated brackish-water $(20 \%$ S) recirculated system with and without the addition of the surfactant Corexit 7664. Arrow indicates end of cadmium dosing

\section{Effects of treatment on flounders}

No apparent ill effects of the cadmium and Corexit 7664 treatment, either separately or combined, could be observed on the experimental animals. There was only little mortality, with 4 dead in the cadmium contaminated system and one dead specimen in each other system. Growth (weight and length) was almost equal in all experiments (Fig. 6); the slightly better growth of the control specimens was not significant. 


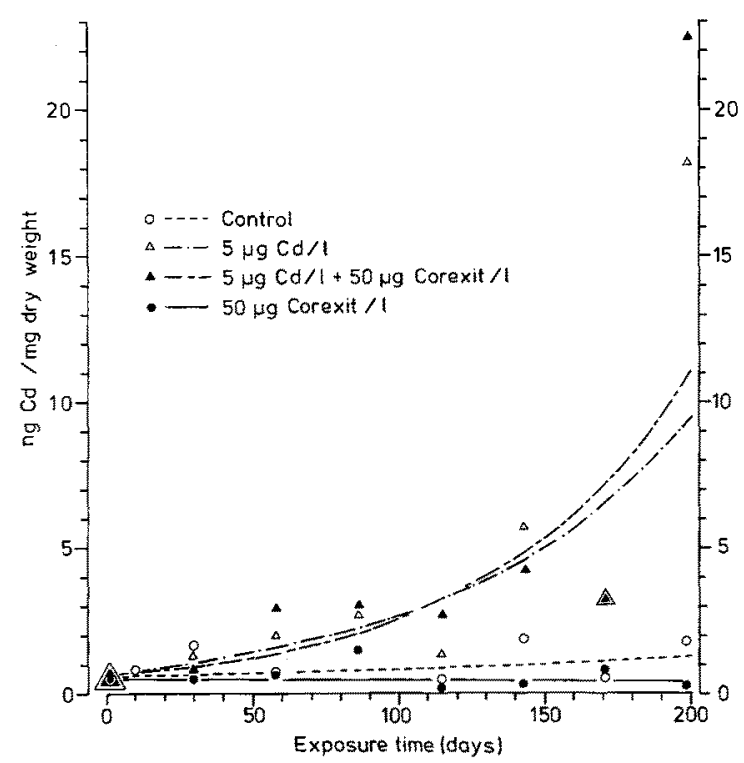

Fig. 5. Accumulation of cadmium in the liver of flounder (Platichthys flesus) during exposure to $5 \mu \mathrm{g}$ $\mathrm{Cd} / 1$ in a recirculated brackish-water $\left(20 \%\right.$ S) system at $15^{\circ} \mathrm{C}$, with and without the addition of $50 \mu \mathrm{g} / \mathrm{l}$ Corexit 7664. Each symbol represents means from 3 test animals and several measurements. $5 \mu \mathrm{g} \mathrm{Cd} / 1: \mathrm{y}=0.722 \mathrm{e}^{0.0128 x}, \mathrm{r}=0.84 ; 5 \mu \mathrm{g} \mathrm{Cd} / 1+50 \mu \mathrm{g}$ Corexit/l: $\mathrm{y}=0.602 \mathrm{e}^{0.0145 \mathrm{x}}, \mathrm{r}=0.87$

\section{DISCUSSION}

\section{Effects of oil dispersants}

When viewing our results in the light of work performed by other authors we may say that at the concentrations of Corexit $7664(10$ to $50 \mu \mathrm{g} / \mathrm{l})$ employed by us, effects on mortality or on growth of experimental animals were not to be expected, since Corexit 7664, being of relatively low toxicity to marine organisms (Lønning \& Falk-Petersen, 1978; Kiceniuk et al., 1978; Wilson, 1973), exerted effects only on sensitive organisms such as sea urchin larvae at concentrations of more than $10 \mathrm{mg} / 1$ (Lønning \& FalkPetersen, 1978).

Toxic concentrations of Corexit 7664 at $48 \mathrm{~h} \mathrm{LC} \mathrm{LC}_{50}$-experiments with Crangon and Cardium were found to be 3300 to $10000 \mathrm{mg} / \mathrm{l}$ (Wilson, 1973). It is known, though, that the gills of aquatic organisms, being the site of the uptake of surfactants (Granmo \& Kollberg, 1976), are sensitive to detergents at relatively low concentrations (Brown et al., 1968). The gills of the mollusc, Patella vulgata, for instance react to oil dispersants at concentrations of $0.1 \mathrm{mg} / 1$ (Nuwayhid et al., 1980). Since it is generally assumed that the gills are an important site for the uptake of water-dissolved heavy metals by fish (NoëlLambot \& Bouquegneau, 1977) and mussel (George et al., 1978), the effects of dispersants on gills might also influence cadmium uptake and tissue concentration.

At the concentration used in our experiment $(10 \mu \mathrm{g}-50 \mu \mathrm{g}$ Corexit/1), a concentration which is likely to occur in the water column after the use of the surfactant in the sea, we 

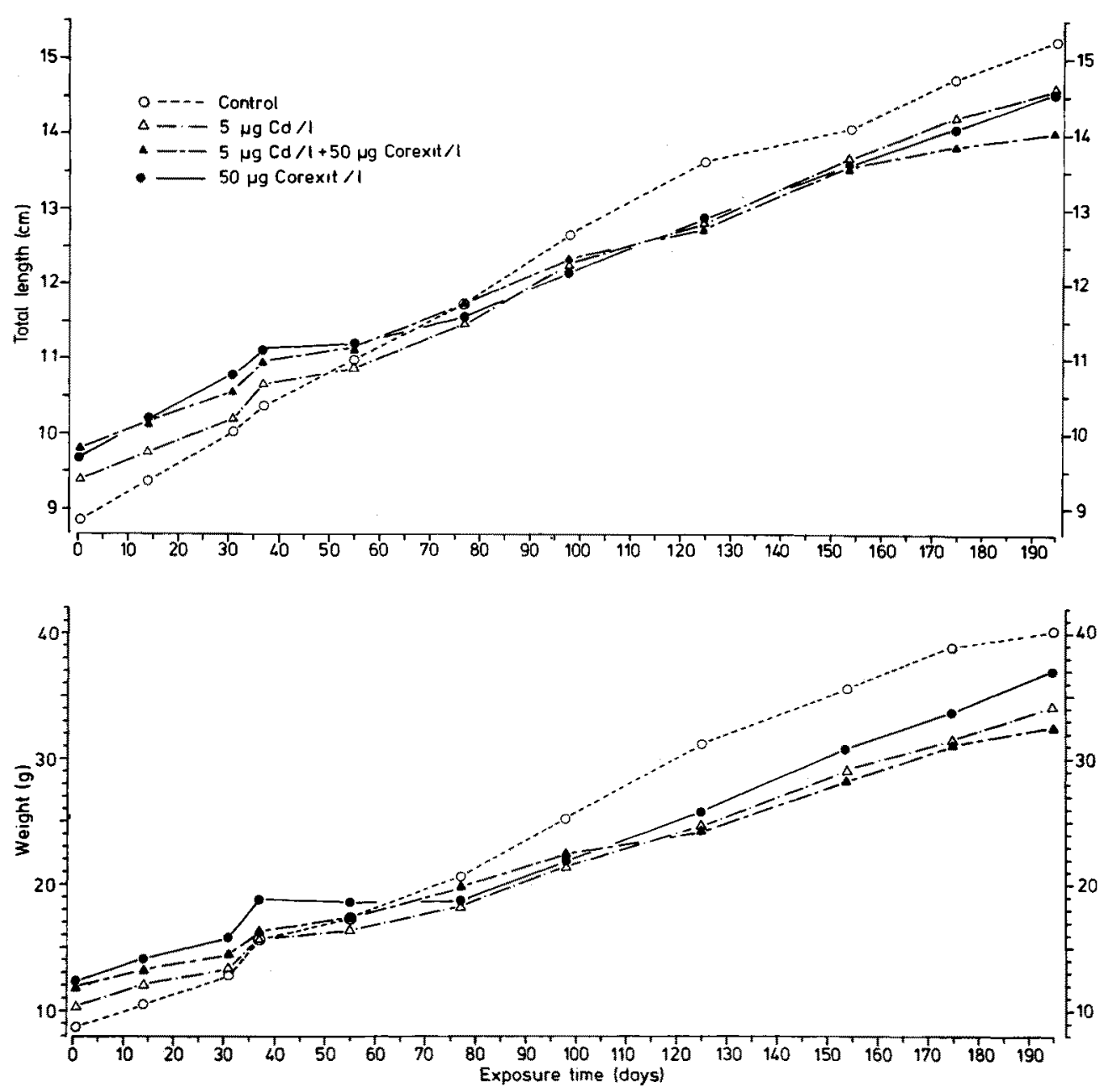

Fig. 6. Growth of flounders in a recirculated brackish-water $(20 \% \mathrm{~S})$ system at $15^{\circ} \mathrm{C}$, with differently treated water. Food: Mytilus edulis and fish-shrimp paste at $15 \%$ of total body weight

found that Corexit 7664 neither increased the cadmium accumulation in the biological sludge, the common mussel or in flounders, nor did it cause any acute ill-effects alone or in combination with cadmium present at $5 \mu \mathrm{g} / \mathrm{l}$.

In fact, the combined action of a surfactant and metals does not seem to be clear cut as shown, for example, by the investigations of Calamari \& Marchetti (1973) who found that for anionic detergents and metals synergistic effects were to be expected, while copper and a non-ionic surfactant would have antagonistic effects on each others' acute toxicity to rainbow trout. Similar results on the synergistic action of alkylbenzene sulphonate and zinc have been reported by Brown et al., (1968), while Bianucci \& Legnani (1974) reported antagonistic effects of simultaneously used dodecylbenzene sulphonate and chromium, and Swedmark \& Granmo (1979) in their experiments with 
cod eggs showed that linear alkylbenzene sulphonate (LAS) generally decreased copper toxicity while zinc decreased the toxicity of LAS.

Since growth is a good indicator of the well-being of a test animal, and since there were no significant growth differences in all experimental groups with or without treatment, we can say that there were no ill effects at the concentrations and for the exposure time employed during the experiment.

\section{Cadmium accumulation}

The concentration levels of cadmium observed deviated considerably from the data obtained by us in previous experiments with plaice (Westernhagen et al., 1978), where the salinity of the experimental seawater was $33 \%$. Although the cadmium concentrations employed in both experiments were in the range of $5 \mu \mathrm{g} / \mathrm{l}$, accumulation in the present experiments was far more pronounced, showing values of around $20.0 \mathrm{ng} \mathrm{Cd} / \mathrm{mg}$ dry wt for flounder liver, after 200 days of exposure, instead of $4.0 \mathrm{ng} \mathrm{Cd} / \mathrm{mg}$ dry wt in the plaice experiments. Mussel tissue of the previous experiments contained only $100.0 \mathrm{ng}$ $\mathrm{Cd} / \mathrm{mg}$ dry wt after 160 days compared to 300.0 and $400.0 \mathrm{ng} \mathrm{Cd} / \mathrm{mg}$ dry wt for tissue and $700.0 \mathrm{ng} \mathrm{Cd} / \mathrm{mg}$ dry wt for the digestive gland in the present experiment. Similarly, cadmium content of sludge was 4 times higher in the present experiments.

Differences in salinities accounted for the four-fold higher accumulation of cadmium by animal tissue in the present experiments (20\% S) compared to the previous ones (33\%) (Westernhagen et al., 1980). The effect of salinity on the accumulation of cadmium by living tissue was found to be much more pronounced than the effect of Corexit 7664. A salinity effect has already been described by us in incubation experiments with flounder, and garpike eggs (Westernhagen et al., 1975; Westernhagen \& Dethlefsen, 1975), and also other investigators have proved the enhancing effect of low salinities on uptake of cadmium by marine animals such as the crabs Uca pugilator (O'Hara, 1973), Callinectes sapidus Rathbun (Hutcheson, 1974) and Carcinus maenas (Wright, 1977) and the common mussel Mytilus edulis (Phillips, 1976). Naturally occurring populations of $M$. edulis in the Baltic Sea also showed that at low salinities cadmium content of soft tissue was up to one order of magnitude higher (Phillips, 1977) than in more saline waters.

As found by us in our previous experiments (Westernhagen et al., 1978) as well as by George \& Coombs (1977) and Scholz (1980) and shown by Schulz-Baldes (1974) for the uptake of lead, the accumulation of cadmium by $M$. edulis was linear, causing the mussel to enrich cadmium to an extent not found in the natural environment, where concentrations of $34 \mathrm{ppm}$ in Kiel Fjord mussels (Theede et al., 1979) are considered to be exceptionally high.

Accumulation of cadmium by filter sludge was also linear and the highest values reached were about 4 times higher than in experiments conducted in undiluted sea water.

The reason why cadmium is accumulated more at low salinities than at high salinities is not clear. O'Hara (1973) sees this salinity effect as being the result of increased ionic regulatory activity at low salinities involving accelerated active uptake of ions, while Hutcheson (1974) attributes the increased cadmium accumulation in dilute sea water - in the case of the crab Callinectes sapidus - to a deterioration in the efficient 
excretion of the metal under conditions of osmotic stress. In our experiments, though, well adapted brackish-water organisms were used, ruling out the latter possibility; and neither do Wright's (1977) experiments with Carcinus maenas nor the investigations of George et al. (1978) with $M$. edulis answer this question satisfactorily.

The uptake of cadmium by the organisms is probably a non-active process, which might be accelerated and facilitated by the chelation with humic acids (George \& Coombs, 1977). These acids are more abundant in brackish water than in full strength sea water and thus the faster cadmium accumulation in brackish water may be explained. Further detailed work, however, is required to elucidate the exact mechanism of the salinity effect.

As further experimental evidence becomes available, the often expressed concern that synergistic effects might ensue from the simultaneous action of certain pollutants does not materialize. This corresponds with the conclusion formulated by EIFAC (1980): the joint, acutely lethal toxicity of pollutants to fish as well as the uptake of combinations of pollutants can be described by using the concentration-addition model (Anderson \& Weber, 1975). Combined effects of pollutants will frequently be much less pronounced than the impact caused by one toxicant and varying natural conditions such as salinity in estuaries.

Acknowledgements. We are indebted to G. Fürstenberg and E. Ropers for expert technical assistance during the experiments.

\section{LITERATURE CITED}

Abdullah, M. J., Royle, L. G. \& Morris, A. W., 1972. Heavy metal concentration in coastal waters. Nature, Lond. 235, 158-160.

Anderson, P. \& Weber, L. J., 1975. The toxicity to aquatic populations of mixtures containing certain heavy metals. In: Proceedings of the International Conference on Heavy Metals in the Environment, October 27-31, 1974. Institute of Environmental Studies, University of Toronto, Canada, 933-953.

Bianucci, F. \& Legnani, P., 1974. Ricerche sulla tossicita di miscele di cromo-detergente anionico per l'Alburnus alburnus varieta alborella. - Ig. mod. 66, 531-537.

Brown, V. M., Mitrovic, V. V. \& Stark, G. T. C., 1968. Effects of chronic exposure to zinc on toxicity of a mixture of detergent and zinc. - Wat. Res. 2, 255-263.

Calabrese, A., Thurberg, F. P., Dawson, M. A. \& Wenzloff, D. R., 1975. Sublethal physiological stress induced by cadmium and mercury in the winter flounder, Pseudopleuronectes americanus. In: Sublethal effects of toxic chemicals on aquatic animals. Ed. by J. H. Koemann \& J. J. T. W. A. Strik. Elsevier, Amsterdam, 15-21.

Calamari, D. \& Marchetti, R., 1973. The toxicity of mixtures of metals and surfactants to rainbow trout (Salmo gairdneri Rich.). - Wat. Res. $7_{t}$ 1453-1464.

Coleman, N, 1980. The effect of emersion on cadmium accumulation by Mytilus edulis. - Mar. Pollut. Bull. 11, 359-362.

Duinker, J. C. \& Nolting, R. F., 1978. Mixing, removal and mobilization of trace metals in the Rhine estuary. - Neth. J. Sea Res. 12, 205-223.

Eifac, 1980. Report on combined effects on freshwater fish and other aquatic life of mixtures of toxicants in water. - E. I. F. A. C. techn. Pap, 37, 1-49.

Elinder, C.-G. \& Kjelström, T., 1977. Cadmium concentrations in samples of human kidney cortex from the 19th century. - Ambio 6, 270-272.

George, S. G. \& Coombs, T. L., 1977. The effects of chelating agents on the uptake and accumulation of cadmium by Mytilus edulis. - Mar. Biol. 39, 261-268.

George, S. G., Carpene, E. \& Coombs, T. L., 1978. The effect of salinity on the uptake of cadmium by the common mussel Mytilus edulis (L.). In: Physiology and behavious of marine organisms. Ed. by D. S. McLusky \& A. J. Berry. Pergamon Pr., New York, 189-193. 
Granmo, A. \& Kollberg, S., 1976. Uptake pathways and elimination of a nonionic surfactant in cod (Gadus morrhua L.). - Wat. Res. 10, 189-194.

Harms, U., 1975. The levels of heavy metals $(\mathrm{Mn}, \mathrm{Fe}, \mathrm{Co}, \mathrm{Ni}, \mathrm{Cu}, \mathrm{Zn}, \mathrm{Cd}, \mathrm{Pb}, \mathrm{Hg})$ in fish from onshore and offshore waters of the German Bight. - Z. Lebensmittelunters. -Forsch. 157, 125-132.

Harris, J. E., Fabris, G. J., Statham, P. J. \& Tawfik, F., 1979. Biogeochemistry of selected heavy metals in Western Port, Victoria, and use of invertebrates as indicators with emphasis on Mytilus edulis planulatus. - Aust. J. mar. Freshwat. Res. 30, 159-178.

Hershelman, G. P., Schafer, H. A., Jan, T.-K. \& Young, D. R., 1981. Metals in marine sediments near a large California municipal outfall. - Mar. Pollut. Bull. 12, 131-134.

Hutcheson, M. S., 1974. The effect of temperature and salinity on cadmium uptake by the blue crab, Callinectes sapidus. - Chesapeake Sci. 15, 237-241.

Karbe, L., Schnier, C. \& Siewers, H. O., 1977. Trace elements in mussels (Mytilus edulis) from coastal areas of the North Sea and the Baltic. Multielement analyses using instrumental neutron activation analysis. - J. radioanalyt. Chem. 37, 927-943.

Kiceniuk, J. W., Penrose, W. R. \& Squires, W. R., 1978. Oil spill dispersants cause bradycardia in a marine fish. - Mar. Pollut. Bull. 9, 42-45.

Larsson, A., Bengtsson, B.-E. \& Haux, C., 1981. Disturbed ion balance in flounder, Platichthys flesus L., exposed to sublethal levels of cadmium. - Aquat. Toxic. 1, 19-35.

Lønning, S. \& Falk-Petersen, I.-B., 1978. The effects of oil dispersants on marine eggs and larvae. Astarte 11, 135-138.

Mann, H. \& Schöberl, P., 1976. Der biologische Abbau eines nichtionischen Tensides in Brackwasser. - Arch. FischWiss. 26, 177-180.

Nelson-Smith, A.3 1968. The effects of oil pollution and emulsifier cleansing on shore life in southwest Britain. - J. appl. Ecol. 5, 97-107.

Noël-Lambot, F. \& Bouquegneau, J. M., 1977. Comparative study of toxicity, uptake and distribution of cadmium and mercury in the sea water adapted eel Anguilla anguilla. - Bull. environ. Contam. Toxicol. 18, 418-424.

Nuwayid, M. A., Davies, P. S. \& Elder, H. Y., 1980. Changes in the ultrastructure of the gill epithelium of Patella vulgata after exposure to North Sea crude oil and dispersants. - J. mar. biol. Ass. U. K. $60,439-448$.

O'Hara, J, 1973. Cadmium uptake by fiddler crabs exposed to temperature and salinity stress. $-\mathrm{J}$. Fish. Res. Bd Can. 30, 846-848.

Pentreath, R. J., 1977. The accumulation of cadmium by the plaice, Pleuronectes platessa L. and the thormback ray, Raja clavata L. - J. exp. mar. Biol. Ecol. 30, 223-232.

Phillips, D. J. H., 1976. The common mussel Mytilus edulis as an indicator of pollution by zinc, cadmium, lead and copper. I. Effects of environmental variables on uptake of metals. - Mar. Biol. $38,59-69$.

Phillips, D. J. H. 1977. The common mussel Mytilus edulis as an indicator of trace metals in Scandinavian waters. II. Zinc and cadmium. - Mar. Biol. 43, 283-292.

Scholz, N., 1980. Accumulation, loss and molecular distribution of cadmium in Mytilus edulis. Helgoländer Meeresunters. 33, 68-78.

Schulz-Baldes, M., 1974. Lead uptake from the sea water and food, and lead loss in the common mussel Mytilus edulis. - Mar. Biol. 25, 177-193.

Swedmark, M. \& Granmo, A., 1979. Effects of mixtures of heavy metals and a surfactant on the development of cod (Gadus morrhua L.). - C. M. - I. C. E. S. P 5, 1-17.

Theede, H., Andersson, 1. \& Lehnberg, W., 1979. Cadmium in Mytilus edulis from German coastal waters. - Meeresforschung 27, 147-155.

Topping. G., 1973. Heavy metals in fish from Scottish waters. - Aquaculture 1, 373-377.

Weijden, C. H. van der, Arnoldus, M. J. H. L. \& Meurs, C. J., 1977. Desorption of metals from suspended material in the Rhine estuary. - Neth. J. Sea Res. 11, 130-145.

Westermhagen, H, von \& Dethlefsen, V., 1975. Combined effects of cadmium and salinity on development and survival of flounder eggs. - J. mar. biol. Ass. U. K. 55, 945-957.

Westernhagen, H. von, Dethlefsen, V. \& Rosenthal, H., 1975. Combined effects of cadmium and salinity on development and survival of garpike eggs. - Helgoländer wiss. Meeresunters. 27, $268-282$. 
Westernhagen, H. von, Dethlefsen, V., Rosenthal, H., Fürstenberg, G. \& Klinckmann, J., 1978. Fate and effects of cadmium in an experimental marine ecosystem. - Helgoländer wiss. Meeresunters. $31,471-484$.

Westernhagen, H. von, Dethlefsen, V., \& Rosenthal, H., 1980. Correlation between cadmium concentration in the water and tissue residue levels in the dab, Limanda limanda L., and plaice, Pleuronectes platessa L. - J. mar. biol. Ass. U. K. 60, 45-58.

Wilson, K. W., 1973. Toxicity testing for ranking oils and oil dispersants. In: Proceedings of a Workshop of the UK Institute of Petroleum, December 1972, 11-22.

Wright, D. A., 1977. The effect of salinity on cadmium uptake by the tissues of the shore crab Carcinus maenas. - J. exp. Biol. 67, 137-146. 